\title{
High lipid content and productivity of microalgae cultivating under elevated carbon dioxide
}

\author{
Y-T Huang $\cdot$ C-P Su
}

Received: 6 April 2012/Revised: 3 June 2012/Accepted: 3 March 2013/Published online: 20 March 2013

(C) Islamic Azad University (IAU) 2013

\begin{abstract}
This study examined the cell growth rate, lipid contents, lipid productivity, chlorophyll $a$ concentration, and carbon dioxide tolerance of Chlorella vulgaris under various cultivation conditions. The $\mathrm{pH}$, concentration of carbon dioxide in media, and light intensity variables were manipulated to obtain high lipid productivity. The optimum conditions were at $\mathrm{pH} 7.0,2,930$ lux, and $30 \%$ carbon dioxide. Biomass concentration reached 1,288, 1,130 , and $1,083 \mathrm{mg} \mathrm{L}^{-1}$ at 15,30 , and $50 \% \mathrm{CO}_{2}$ after 6 days, respectively, implying that this strain has appreciable tolerance to carbon dioxide. The highest concentration of chlorophyll $a$ occurred at 2,930 lux and decreased with increasing light intensity gradually. The maximum specific growth rate was $3.25 \mathrm{day}^{-1}$ based on the dry weight and 4.63 day $^{-1}$ based on the cell number. The lipid content $(45.68 \%)$ and lipid productivity (86.03 $\mathrm{mg} \mathrm{day}{ }^{-1} \mathrm{~L}^{-1}$ ) obtained in this study are higher than reported values in literatures. Hence, $C$. vulgaris is a good candidate for subsequent research in biodiesel production under elevated carbon dioxide concentration by microalgae.
\end{abstract}

Keywords Biodiesel $\cdot$ Chlorella $\cdot$ Global warming $\cdot$ Light intensity

Electronic supplementary material The online version of this article (doi:10.1007/s13762-013-0251-y) contains supplementary material, which is available to authorized users.

Y.-T. Huang $(\bowtie) \cdot$ C.-P. Su

Department of Bioenvironmental Engineering, Chung Yuan

Christian University, No. 200, Chung-Pei Road, Chung-Li

32023, Taiwan

e-mail: yt_huang@cycu.edu.tw

\section{Introduction}

Energy shortage has become a pressing global concern. The production of ethanol from plants to microorganisms and its related metabolic pathways and purification procedures have been widely studied. Cellulose can be converted to bioethanol and other useful biofuel resources, such as furfural (Hsu et al. 2011). The microorganism-facilitated recovery of biofuel, such as butanol, from waste is a current research topic (Chen et al. 2011).

Biodiesel is receiving substantial attention for its superiority over fossil fuels. It is not only a renewable energy source, but also a clean energy source because it does not contain sulfur or nitrogen oxide (Hill et al. 2006; Refaat 2009). Biodiesel is better suited to current transportation means than bioethanol, as it requires almost no modification of present transportation infrastructure and has already used by several countries (Mata et al. 2010). Many researchers have attempted to increase the productivity of biodiesel and decreased its production cost (Ma and Hanna 1999; Refaat et al. 2008). Selecting a suitable organism as biodiesel producer plays an important role in this process (Marchetti et al. 2007; Rosenberg et al. 2008). Microalgae have the most promising characteristics of currently known biodiesel producers (Gouveia and Oliveira 2009).

Microalgae can photosynthesize efficiently on a large scale even with not much space and water, and therefore do not displace food crops (Gouveia and Oliveira 2009). Microalgae consume carbon dioxide, which serves as a major cause of global warming. Moreover, carbon dioxide $\left(\mathrm{CO}_{2}\right)$ from flue gas can be used as a substrate to cultivate microalgae to decrease production cost and $\mathrm{CO}_{2}$ emission (Hamasaki et al. 1994; Douskova et al. 2009). Microalgae contain abundant lipids (raw materials for biodiesel), carbohydrates (raw materials for bioethanol), and valuable 
nutrients, such as protein and chlorophyll $a$ (Raja et al. 2008). One species of microalgae, Chlorella vulgaris, is ideal for biodiesel production because of its easier cultivation and higher photosynthetic efficiency as compared to terrestrial plants, and wide applicability (Griffiths and Harrison 2009; Keffer and Kleinheinz 2002). Although few strains, such as Botryococcus sp., are richer in lipid content (Huang et al. 2013), C. vulgaris is still outstanding in lipid productivity (Hsieh and Wu 2009; Lv et al. 2010). Moreover, $C$. vulgaris can be acclimated to high concentrations of $\mathrm{CO}_{2}$, rendering it suitable for commercial cultivation with flue gas as a source of $\mathrm{CO}_{2}$ (Maeda et al. 1995; Douskova et al. 2009).

Optimizing the cultivation conditions and increasing $\mathrm{CO}_{2}$ tolerance are indispensable to the efficient application of C. vulgaris. Flue gas contains $10-20 \% \mathrm{CO}_{2}$ on an average, including sulfides and/or nitrogen oxide compounds. If $C$. vulgaris can acclimate to higher $\mathrm{CO}_{2}$ level and use it as a carbon source, using flue gas as a carbon source can decrease both the cost of biodiesel production and its effect on global warming.

This study identified the cultivation parameters for high lipid content and lipid productivity under $\mathrm{CO}_{2}$ resistance conditions. The effects of $\mathrm{pH}$, light intensity, and $\mathrm{CO}_{2}$ concentration on the growth of $C$. vulgaris strain NIES2173 were investigated. Biomass, cell number, and amount of chlorophyll $a$ were measured to characterize the growth behavior of the microalgae. This work was done at Chung Yuan Christian University, Taiwan, and was completed in March 2012.

\section{Materials and methods}

Microalgae and culture medium

Freshwater C. vulgaris NIES-2173 was purchased from National Institute for Environmental Studies, Tsukuba, Japan. The medium used for cultivation was BG-II (Rippka et al. 1979) with modification, which consisted of $1.5 \mathrm{~g}$ $\mathrm{NaNO}_{3}, 0.04 \mathrm{~g} \mathrm{~K}_{2} \mathrm{HPO}_{4}, 0.075 \mathrm{~g} \mathrm{MgSO}_{4} \cdot 7 \mathrm{H}_{2} \mathrm{O}, 0.036 \mathrm{~g}$ $\mathrm{CaCl}_{2} \cdot 2 \mathrm{H}_{2} \mathrm{O}, 0.006 \mathrm{~g}$ citric acid, $0.006 \mathrm{~g}$ ferric ammonium citrate, $0.001 \mathrm{~g}$ EDTA, $0.02 \mathrm{~g} \mathrm{Na}_{2} \mathrm{CO}_{3}$, and $1 \mathrm{ml}$ trace metal solution for every $1 \mathrm{~L}$ of cultivation medium. The prescription for trace metal solution was $1.575 \mathrm{~g}$ $\mathrm{FeCl}_{3} \cdot 6 \mathrm{H}_{2} \mathrm{O}, 0.090 \mathrm{~g} \mathrm{MnCl}_{2} \cdot 4 \mathrm{H}_{2} \mathrm{O}, 0.011 \mathrm{~g} \mathrm{ZnSO}_{4} \cdot 7 \mathrm{H}_{2} \mathrm{O}$, $0.005 \mathrm{~g} \mathrm{CoCl}_{2} \cdot 6 \mathrm{H}_{2} \mathrm{O}, 0.005 \mathrm{~g} \mathrm{CuSO}_{4} \cdot 5 \mathrm{H}_{2} \mathrm{O}$, and $0.003 \mathrm{~g}$ $\mathrm{Na}_{2} \mathrm{MoO}_{4} \cdot 2 \mathrm{H}_{2} \mathrm{O}$ for every $500 \mathrm{~mL}$ trace metal solution. Light intensity was measured by a Lux Meter TM 50000 (TOMEI, Tokyo, Japan). Cultivation of algae was conducted with $500 \mathrm{~mL}$ to $2,000 \mathrm{~mL}$ Erlenmeyer flask fabricated with a sampling port situated in the wall of the flasks. The flask was installed with a sparger and an exhaust gas tube fixed at the plug inserted at the top of the flasks. The design of sparger was of loop type hanging in the bottom of the flasks. Sparger surface porosity and average pore size are 0.5 and $1.0 \mu \mathrm{m}$, respectively. The cultivation was put in a thermostat controlled at $30{ }^{\circ} \mathrm{C}$. The source of light was from TL-D fluorescent tubes (Philips International B. V., Amsterdam, Holland) irradiated from the outside of the flasks. The fluorescent tubes were situated around left-right and front-rear of inner wall in the thermostat. Cultivation vessels were manufactured by DURAN Group (Mainz, Germany). Aeration rates were kept at $0.5 \mathrm{vvm}$ throughout the experiments. Samples were taken via sampling port with an antiseptic syringe.

Determination of dry weight and cell number

A $10 \mathrm{~mL}$ suspensions of algae were filtered through preweighted dried filter paper washed with distilled water to remove impurities, then dried under $100{ }^{\circ} \mathrm{C}$ and weighed to obtain algae dry weight (DW).

The sample was serially diluted and then counted using a hemacytometer (Marienfeld, Lauda-Königshofen, Germany). The number was then multiplied by the dilution ratio to obtain the cell number in the unit cells $\mathrm{mL}^{-1}$.

Measurement of chlorophyll $a$

The concentration of chlorophyll $a$ can reflect the growth condition of microalgae. To measure chlorophyll $a$, the experiments in this study adopted the National Institute of Environmental Analysis (NIEA), number E508.00B (Environmental Analysis Laboratory, EPA, Executive Yuan, Taiwan 2002).

Determination of lipid content

Microalgae were harvested, centrifuged, frozen, and lyophilized to obtain dried algae powder. The algae powder was weighed and then extracted with a chloroform/methanol mixture of $1: 2(\mathrm{v} / \mathrm{v})$ with ultrasonic waves. The chloroform layer was collected, dried, and weighed to obtain total lipid content (Bligh and Dyer 1959).

Lipid content (\%)

$=$ Weight of lipid $/$ weight of dry algae powder $\times 100 \%$

Experimental parameters

The effects of different $\mathrm{pH}(7,8,9$, and 10$)$ were observed in batch cultures under $30{ }^{\circ} \mathrm{C}, 9,600$ lux (134 micro mol photon $\mathrm{m}^{-2} \mathrm{~s}^{-1}$ ), and $0.5 \mathrm{vvm}$ air. The effects of different light intensities $(1,670,2,930,4,730$, and 9,600 lux) were 
observed in batch cultures under $30{ }^{\circ} \mathrm{C}, 0.5 \mathrm{vvm}$ air and $\mathrm{pH}$ 7. The effects of $\mathrm{CO}_{2}$ were observed under $30{ }^{\circ} \mathrm{C}, 2,930$ lux, and $\mathrm{pH} \mathrm{7,} \mathrm{with} 0.5 \mathrm{vvm}$ input of gaseous mixtures of air and pure $\mathrm{CO}_{2}\left(0,15,30,50,100 \% \mathrm{CO}_{2}\right)$. Samples were taken from the cultivation vessel at 12-h intervals for 144 h. Data were measured in triplicate.

Data analysis

Lipid productivity was calculated using Eq. 2, and the specific growth rate $(\mu)$ was calculated using Eq. 3 .

Lipid productivity $\left(\mathrm{mg} \mathrm{d}^{-1} \mathrm{~L}^{-1}\right)$

$=\mathrm{DW} \times$ lipid content $/ 6$ days

$\begin{aligned} \mu\left(\mathrm{d}^{-1}\right)= & {\left[\ln (\text { cell number })_{2}-\ln (\text { cell number })_{1}\right] / } \\ & \left(t_{2}-t_{1}\right)\end{aligned}$

\section{Results and discussion}

Cell growth and chlorophyll $a$ content at various operational conditions

Figures 1, 2 and 3 show the variations in algae dry weight and chlorophyll $a$ concentration in algae over time at various operational conditions. Figure 1 reveals that the highest algal dried weight $\left(1,137 \mathrm{mg} \mathrm{L}^{-1}\right)$ and chlorophyll $a$ concentration were obtained at $\mathrm{pH} 7$. Further, the greatest net specific growth rate, maximum specific growth rate and accumulated cell number occurred at $\mathrm{pH} 7$ (supplement information, Table S1). Therefore, $\mathrm{pH} 7$ was chosen for optimum $\mathrm{pH}$ in successive experiments to find the optimum light intensity and $\mathrm{CO}_{2}$ concentration.

Figure 2 shows the effects of light intensity on cell growth and chlorophyll $a$ concentration. The concentration of chlorophyll $a$ (Fig. 2b) attained the highest values at a light
Fig. 1 Time course of (a) dry weight and (b) chlorophyll $a$ concentration in cultivation of C. vulgaris NIES-2173 under various $\mathrm{pHs}$
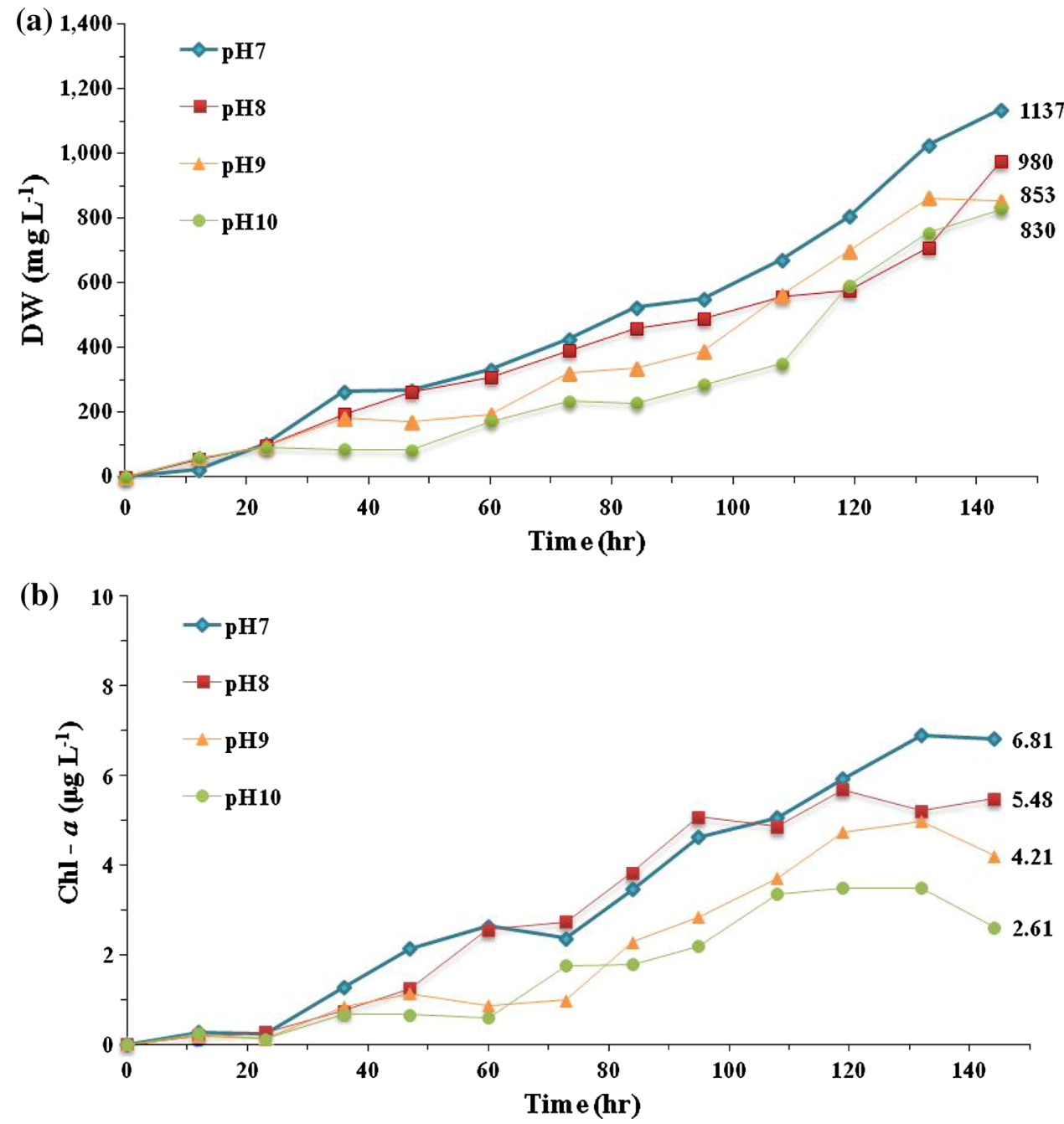
Fig. 2 Time course of (a) dry weight and (b) chlorophyll $a$ concentration in cultivation of C. vulgaris NIES-2173 under various light intensities
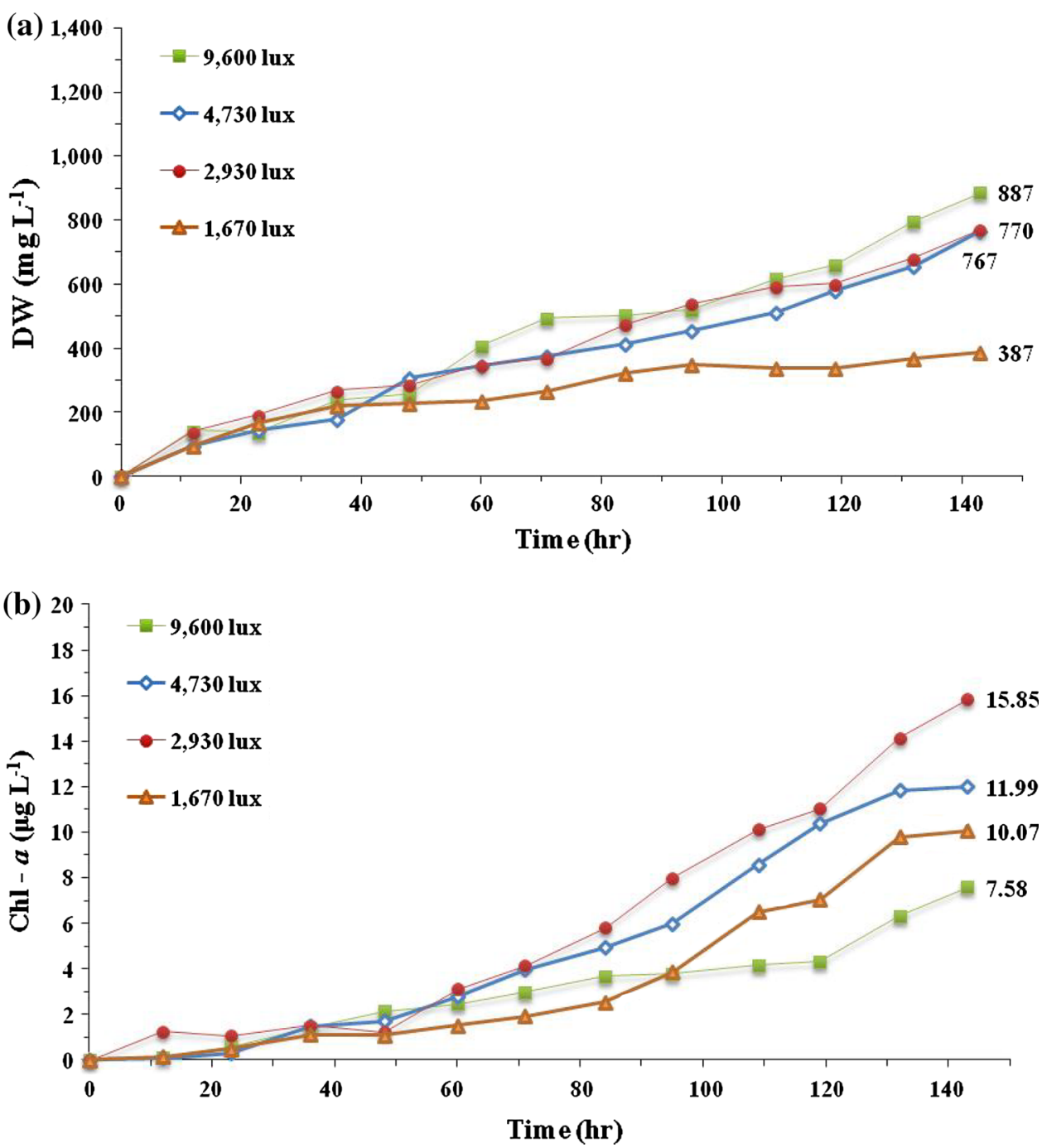

intensity of 2,930 lux, and decreased gradually with increasing light intensity. These results imply that the light inhibition occurred beyond 2,930 lux. Therefore, 2,930 lux was chosen as the optimum light intensity for examining the effects of $\mathrm{CO}_{2}$ concentration on cell growth and chlorophyll $a$ content. However, the highest dry weight $\left(887 \mathrm{mg} \mathrm{L}^{-1}\right)$ occurred at a light intensity of 9,600 lux (Fig. 2a). This phenomenon will be discussed in the next section.

Figure 3 shows the effects of $\mathrm{CO}_{2}$ concentration on growth and chlorophyll $a$ content in $C$. vulgaris NIES-2173 cells. The highest cell number $\left(1.06 \times 10^{11}\right.$ cells $\mathrm{L}^{-1}$, Table 1) and concentrations of chlorophyll $a$ (Fig. 3b) were obtained in the aeration without supplementing the $\mathrm{CO}_{2}$. The maximum specific growth rate was 4.63 day $^{-1}$, as calculated from the cell number. However, the highest cell mass concentration/dry weight $\left(1,288 \mathrm{mg} \mathrm{L}^{-1}\right)$ appeared at $15 \% \mathrm{CO}_{2}$ (Fig. 3a). At 30 and $50 \% \mathrm{CO}_{2}$, the cell dry weight increased to 1,130 and $1,083 \mathrm{mg} \mathrm{L}^{-1}$, respectively. These results are higher than the cells cultivated only with air $\left(920 \mathrm{mg} \mathrm{L}^{-1}\right)$, indicating the microalgae have $\mathrm{CO}_{2}$ tolerance up to $50 \%$. These results are similar to those obtained by (Maeda et al. 1995).

Figure 3 shows that $C$. vulgaris can grow in 15, 30, and $50 \%$ of $\mathrm{CO}_{2}$, indicating the possibility of using flue gas as a carbon source. Although the previous research indicates that a high $\mathrm{CO}_{2}$ concentration (e.g., $10 \%$, Chiu et al. 2008) inhibits the growth of $C$. vulgaris, the results obtained in the current study show that $C$. vulgaris can grow well in $\mathrm{CO}_{2}$ concentrations ranging from 15 to $50 \%$. Furthermore, analysis of variance (ANOVA) results indicate that $\mathrm{pH}$, light intensity, and $\mathrm{CO}_{2}$ concentration were significant factors affecting the dry weight, with a $p$ value less than 0.01. The $\mathrm{pH}$ and $\mathrm{CO}_{2}$ concentrations were significant factors affecting the concentration of chlorophyll $a$ with $p$ values less than 0.01 , while light intensity with a $p$ value less than 0.05 (supplement information, Table S2). 
Fig. 3 Time course of (a) dry weight and (b) chlorophyll $a$ concentration in cultivation of C. vulgaris NIES-2173 under various concentrations of $\mathrm{CO}_{2}$
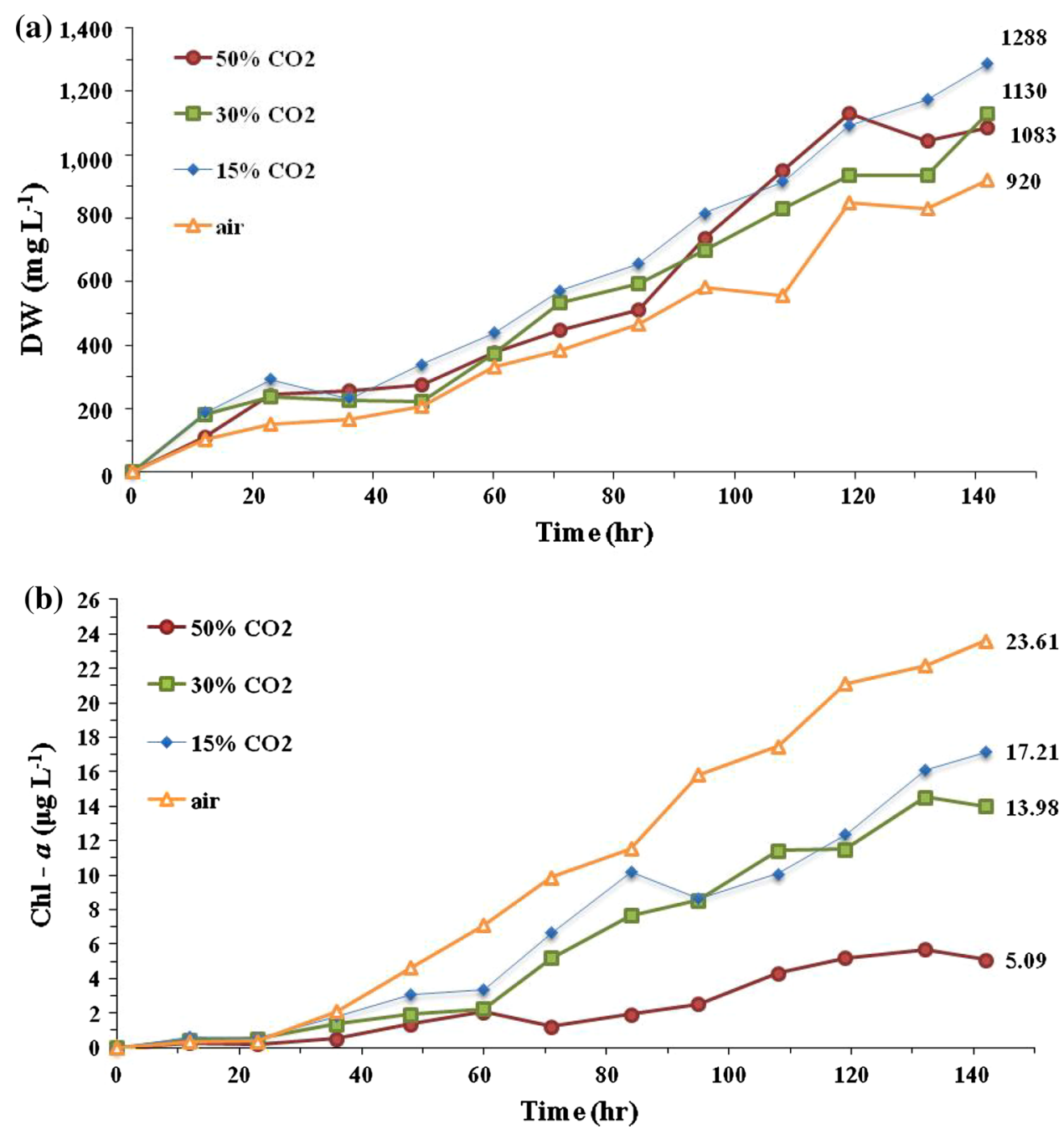

Comparison of constituents in single cells: lipid content and lipid productivity

Chlorella contains protein, carbohydrate, and lipid levels suitable for different applications such as nutritional supplement, bioethanol, and biodiesel (Ramos et al. 2010; Lee et al. 2011; Sun et al. 2011). For more effective application of $C$. vulgaris, it is important to determine the cultivation conditions that influence the constituents of $C$. vulgaris cells (Wang et al. 2010; Kaur et al. 2012; Yeh and Chang 2012). Table 1 shows the dry weight of cells, weight of chlorophyll $a$, and lipid amount of single cells cultured in different conditions. Figure 4 shows the lipid content and productivity under different cultivation conditions.

Table 1 indicates that the biomass, chlorophyll $a$ content, and lipid amount of single cells slightly changed with respect to $\mathrm{pH}$, resulting in a minor decreasing trend in total lipid content (from 25.50 to $24.33 \%$ ) (Fig. 4). The highest values of biomass and lipid amount were 92.1 and $22.38 \mathrm{pg} / \mathrm{cell}$, respectively, obtained at $\mathrm{pH} 10$. Meanwhile, the highest amount of chlorophyll $a$ was obtained at $\mathrm{pH} 8$ (Table 1).

Table 1 shows that the amount of biomass and lipids in single cells increased significantly under greater light intensity. However, the amount of chlorophyll $a$ did not exhibit the same response. The maximum values of dry weight and lipid amount of single cells were 62.0 and $18.06 \mathrm{pg} / \mathrm{cell}$, respectively (Table 1). This phenomenon can be attributed to light-induced algal growth, which promoted the accumulation of extra metabolites, such as carbohydrates and lipids. In addition, the lipid productivity reached the highest value of $43.05 \mathrm{mg} \mathrm{day}^{-1} \mathrm{~L}^{-1}$ at 9,600 lux. These results imply that the cultivation of $C$. vulgaris NIES-2173 at 9,600 lux is suitable for both bioethanol and biodiesel production. Nevertheless, the same level of lipid productivity $\left(41.11 \mathrm{mg}\right.$ day $^{-1} \mathrm{~L}^{-1}$ ) was obtained at the light intensity of 2,930 lux, and the highest lipid content $(32.03 \%)$ was reached (Fig. 4). This indicates that 2,930 lux is a better choice for producing biodiesel, because it requires relatively simple and cheap equipment. 
Table 1 Characteristics of a single $C$. vulgaris NIES-2173 cell cultivated under various conditions

\begin{tabular}{lrllll}
\hline Testing items & & Cell number $\left(\mathrm{L}^{-1}\right)$ & DW (pg/cell) & chlorophyll $a(\text { fg/cell })^{\mathrm{e}}$ & Lipid amount $(\mathrm{pg} / \text { cell })^{\mathrm{f}}$ \\
\hline $\mathrm{pH}$ & 7 & $1.92 \times 10^{10}$ & $59.2 \pm 1.2^{\mathrm{a}}$ & $0.355 \pm 0.022^{\mathrm{a}}$ & $15.11 \pm 0.03^{\mathrm{a}}$ \\
& 8 & $1.12 \times 10^{10}$ & $87.7 \pm 0.0^{\mathrm{ab}}$ & $0.490 \pm 0.019^{\mathrm{ab}}$ & $21.92 \pm 0.00^{\mathrm{ab}}$ \\
& 9 & $1.17 \times 10^{10}$ & $73.2 \pm 0.0^{\mathrm{b}}$ & $0.361 \pm 0.057$ & $18.07 \pm 0.00^{\mathrm{abc}}$ \\
& 10 & $9.01 \times 10^{9}$ & $92.1 \pm 3.7^{\mathrm{a}}$ & $0.289 \pm 0.019^{\mathrm{b}}$ & $22.38 \pm 0.12^{\mathrm{ac}}$ \\
& 1,670 & $3.30 \times 10^{10}$ & $11.7 \pm 0.6^{\mathrm{a}}$ & $0.306 \pm 0.008$ & $3.51 \pm 0.02^{\mathrm{a}}$ \\
Light intensity (lux) & 2,930 & $6.44 \times 10^{10}$ & $12.0 \pm 0.8^{\mathrm{b}}$ & $0.246 \pm 0.045$ & $3.83 \pm 0.03^{\mathrm{ab}}$ \\
& 4,730 & $2.98 \times 10^{10}$ & $25.8 \pm 1.3^{\mathrm{abc}}$ & $0.403 \pm 0.060$ & $6.05 \pm 0.04^{\mathrm{abc}}$ \\
& 9,600 & $1.43 \times 10^{10}$ & $62.0 \pm 0.0^{\mathrm{abc}}$ & $0.530 \pm 0.094$ & $18.06 \pm 0.00^{\mathrm{abc}}$ \\
& 0 & $1.06 \times 10^{11}$ & $8.65 \pm 0.27^{\mathrm{a}}$ & $0.222 \pm 0.003^{\mathrm{a}}$ & $2.97 \pm 0.02^{\mathrm{a}}$ \\
& 15 & $7.49 \times 10^{10}$ & $17.2 \pm 0.03^{\mathrm{ab}}$ & $0.230 \pm 0.032$ & $6.06 \pm 0.00^{\mathrm{ab}}$ \\
& 30 & $5.31 \times 10^{10}$ & $21.3 \pm 4.35^{\mathrm{c}}$ & $0.263 \pm 0.061$ & $9.71 \pm 0.11^{\mathrm{abc}}$ \\
& 50 & $3.01 \times 10^{10}$ & $36.1 \pm 1.10^{\mathrm{abd}}$ & $0.170 \pm 0.006^{\mathrm{ad}}$ & $13.15 \pm 0.06^{\mathrm{abcd}}$ \\
& 100 & $3.63 \times 10^{9}$ & $150 \pm 3.90^{\mathrm{abcd}}$ & $0.605 \pm 0.000^{\mathrm{ad}}$ & $45.10 \pm 0.22^{\mathrm{abcd}}$ \\
\hline
\end{tabular}

abcd Significant difference $(P<0.05)$, analyzed with the data compared between ${ }^{\mathrm{a}}$, or ${ }^{\mathrm{b}}$, or ${ }^{\mathrm{c}}$, or ${ }^{\mathrm{d}}$, respectively

e fg/cell: $10^{-15} \mathrm{~g}$ per cell

${ }^{\mathrm{f}} \mathrm{pg} / \mathrm{cell}: 10^{-12} \mathrm{~g}$ per cell

The resulting cell number of C. vulgaris NIES-2173 cultured in $100 \% \mathrm{CO}_{2}$ was $3.63 \times 10^{9}$ cells $\mathrm{L}^{-1}$, which was approximately $3.4 \%$ of that cultured in air. These extreme environmental conditions likely inhibited the reproduction of cells, increasing biomass dry weight, chlorophyll $a$, and lipid per cell (Table 1). The lipid content and lipid productivity of the whole culture was the lowest among the different concentrations of $\mathrm{CO}_{2}$ tested (Fig. 4). Nevertheless, C. vulgaris NIES-2173 was cultivated successfully in $50 \% \mathrm{CO}_{2}$. The amount of biomass and lipid in single cells changed significantly with a higher concentration of $\mathrm{CO}_{2}$, but the amount of chlorophyll $a$ remained almost the same (Table 1). When considering different concentrations of $\mathrm{CO}_{2}$ from 0 to $50 \%$, the highest values of biomass, chlorophyll $a$, and lipid were 36.1 $\mathrm{pg} / \mathrm{cell}, \quad 0.263 \mathrm{fg} / \mathrm{cell}$, and $13.15 \mathrm{pg} / \mathrm{cell}$, respectively (Table 1).

A comprehensive observation of Table 1 and Fig. 4 reveals that the factors influencing the amount of chlorophyll $a$ in single cells are $\mathrm{pH}$ and $\mathrm{CO}_{2}$ concentration, whereas $\mathrm{pH}$, light intensity and concentration of $\mathrm{CO}_{2}$ influenced dry weight and lipid amount of single cells. The lipid content of the whole culture was influenced by both light intensity and concentration of $\mathrm{CO}_{2}$. Lipid productivity was influenced by three factors-both highest lipid content $(45.68 \%)$ and productivity $\left(86.03 \mathrm{mg} \mathrm{day}{ }^{-1} \mathrm{~L}^{-1}\right)$ appear at $30 \% \mathrm{CO}_{2}, 2,930$ lux, and $\mathrm{pH}$ 7.0.

Comparison with other investigators

The results of this study show great competitiveness compared to others. First, this particular strain of $C$. vulgaris has an amazing tolerance toward $\mathrm{CO}_{2}$ (up to $50 \%$ ) compared to the results of Chiu et al. (2008), who showed that the growth of Chlorella is limited by a $\mathrm{CO}_{2}$ concentration exceeding $2 \%$. Furthermore, the lipid content reached its highest value at $30 \% \mathrm{CO}_{2}$, whereas $\mathrm{Lv}$ et al. (2010) showed that lipid content decreased if the $\mathrm{CO}_{2}$ concentration exceeded $1 \%$. Maeda et al. (1995) showed that Chlorella can withstand $50 \% \mathrm{CO}_{2}$, but did not provide data on the lipid content. Thus, the optimum cultivation conditions for producing biodiesel remain uncertain. This study demonstrates that $30 \% \mathrm{CO}_{2}$ is the optimum concentration for biodiesel production, and $15 \% \mathrm{CO}_{2}$ produces the highest dry weight, as corroborated by Maeda et al. (1995).

This study also shows a relatively high lipid productivity (86.03 $\mathrm{mg} \mathrm{day}^{-1} \mathrm{~L}^{-1}$ ) and lipid content (45.68\%). Compared to other studies on freshwater C. vulgaris, this lipid productivity is approximately 10.8 times and 5.8 times that of (Illman et al. 2000) under controlled medium and low-N medium, respectively, and superior to Widjaja et al. (2009) and Yeh et al. (2010) (Table 2). The maximum lipid content $(45.68 \%)$ obtained in this study is also the highest comparing to 18 and $40 \%$ of (Illman et al. 2000), $29.53 \%$ of (Widjaja et al. 2009) and 30-40\% of (Yeh et al. 2010). Nitrogen is usually the important limiting nutrient for most microorganisms. High amount of lipid is expected to accumulate by limiting the nitrogen source. Illman et al. (2000) conducted low nitrogen medium and the lipid content increased from 18 to $40 \%$. The cultivation of C. vulgaris NIES-2173 on nitrogen limitation is in progress. The optimum $\mathrm{CO}_{2}$ concentration in this study is $30 \%$, which is higher than the data published by other investigators (Table 2). This indicates that the strain 
Fig. 4 a Lipid content and b lipid productivity of $C$. vulgaris NIES-2173 cultivated under various conditions

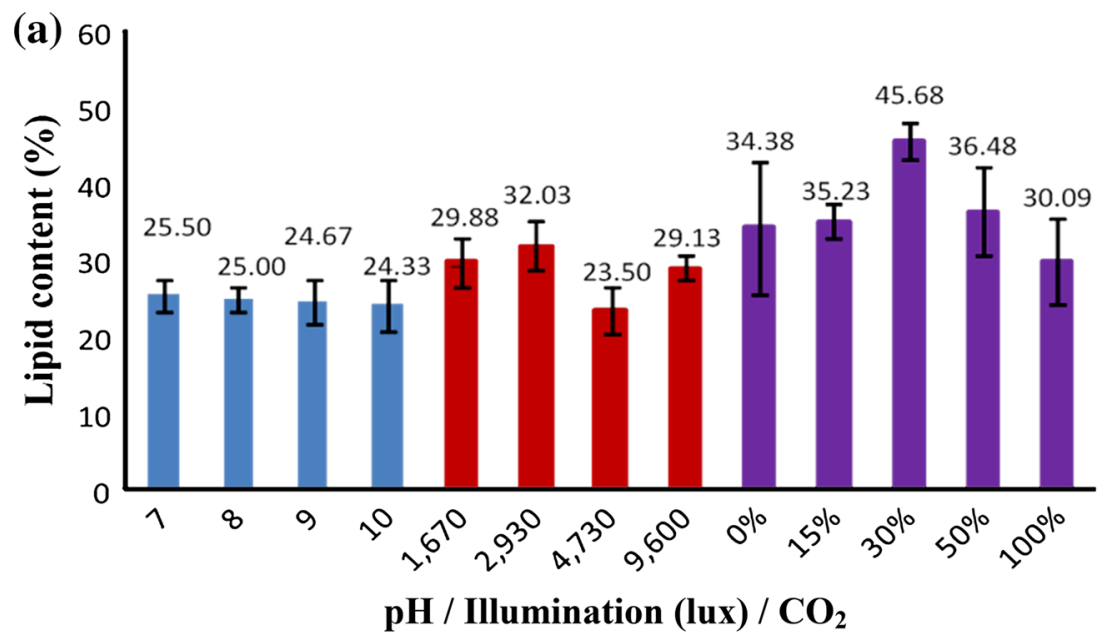

(b)

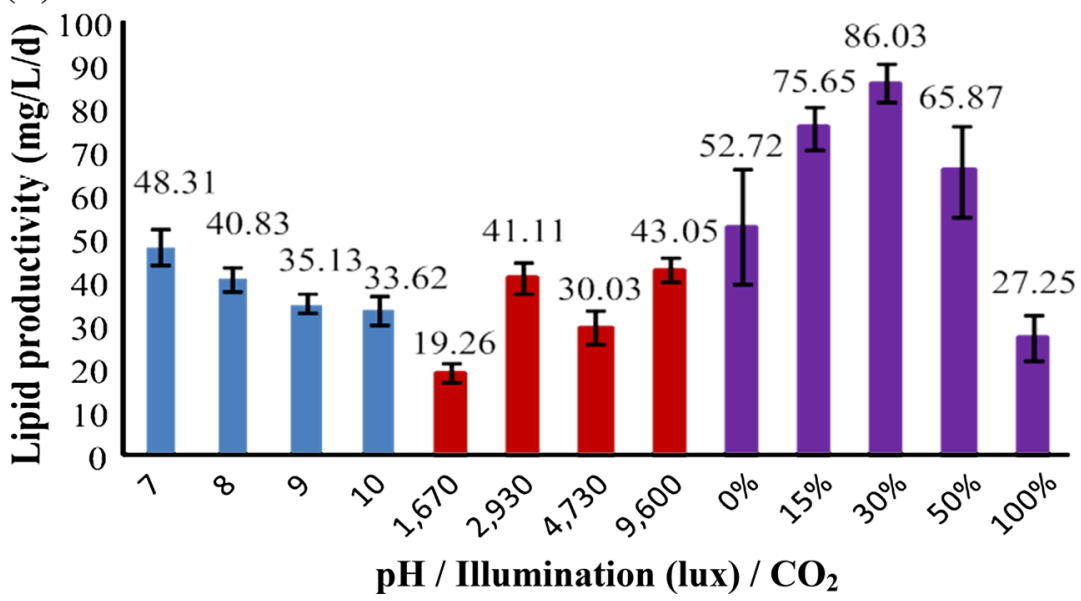

Table 2 Comparison with other investigators

\begin{tabular}{lllll}
\hline $\begin{array}{l}\text { Optimum } \mathrm{CO}_{2} \text { concentration } \\
(\%)\end{array}$ & Lipid content (\%) & Lipid productivity $\left(\mathrm{mg} \mathrm{day}^{-1} \mathrm{~L}^{-1}\right)$ & $\begin{array}{l}\text { Specific growth rate } \\
\left(\text { day }^{-1}\right)\end{array}$ & Reference \\
\hline 10 & - & - & $1.58^{\mathrm{c}}$ (dry weight) & Maeda et al., (1995) \\
5 & 18 & 8 & 0.99 (cell number) & Illman et al., (2000) \\
5 & 40 & 14.8 & 0.77 (cell number) & Illman et al., (2000) \\
0.83 & 29.53 & 12.77 & - & Widjaja et al., (2009) \\
- & $30-40$ & $11.6^{\mathrm{d}}$ & 1.77 (dry weight) & Yeh et al., (2010) \\
30 & 45.68 & 86.03 & 3.25 (dry weight) & This study \\
& & & 4.63 (cell number) & \\
\hline
\end{tabular}

${ }^{a}$ Data were calculated based on Illman et al. (2000) under control medium

b Data were calculated based on Illman et al. (2000) under low-N medium

c Data were calculated based on Maeda et al. (1995)

${ }^{\mathrm{d}}$ Data were calculated based on Yeh et al. (2010)

acclimatized in this study is suitable for use with flue gas as the carbon source. The specific growth rate of this study is approximately 4.7 times that of (Illman et al. 2000), and approximately 1.8 times that of (Yeh et al. 2010). Table 2 compares the results of this study with other investigators.

\section{Conclusion}

Chlorella vulgaris NIES-2173 was cultivated to examine its lipid production performance at optimum conditions: $\mathrm{pH} 7.0,2,930$ lux, and $30 \% \mathrm{CO}_{2}$. The growth of cells 
declined when the $\mathrm{CO}_{2}$ concentration exceeded $50 \%$. The highest lipid content obtained was $45.68 \%$, and the highest lipid productivity was $86.03 \mathrm{mg}$ day $^{-1} \mathrm{~L}^{-1}$. The strain adopted in this study is a good candidate for subsequent research on lipid production under elevated $\mathrm{CO}_{2}$.

Acknowledgments The authors would like to express their utmost respect to Emeritus Professor Shih-Yow Huang, Department of Chemical Engineering, National Taiwan University, for his critical review and valuable suggestions regarding this article. This research was supported by the National Science Council, Taiwan (NSC1012623-E-033-001-ET).

\section{References}

Bligh EG, Dyer WJ (1959) A rapid method of total lipid extraction and purification. Can J Biochem Physiol 37(8):911-917

Chen WH, Chen SY, Chao SJ, Jian ZC (2011) Butanol production from the effluent of hydrogen fermentation. Water Sci Technol 63(6):1236-1240

Chiu SY, Kao CY, Chen CH, Kuan TC, Ong SC, Lin CS (2008) Reduction of $\mathrm{CO}_{2}$ by a high-density culture of Chlorella sp. in a semicontinuous photobioreactor. Bioresour Technol 99(9): 3389-3396

Douskova I, Doucha J, Livansky K, Machat J, Novak P, Umysova D, Zachleder V, Vitova M (2009) Simultaneous flue gas bioremediation and reduction of microalgal biomass production costs. Appl Microbiol Biotechnol 82(1):179-185

Gouveia L, Oliveira A (2009) Microalgae as a raw material for biofuels production. J Ind Microbiol Biotechnol 36(2):269-274

Griffiths M, Harrison S (2009) Lipid productivity as a key characteristic for choosing algal species for biodiesel production. J Appl Phycol 21(5):493-507

Hamasaki A, Shioji N, Ikuta Y, Hukuda Y, Makita T, Hirayama K, Matuzaki H, Tukamoto T, Sasaki S (1994) Carbon dioxide fixation by microalgal photosynthesis using actual flue gas from a power plant. Appl Biochem Biotechnol 45/46(1):799-809

Hill J, Nelson E, Tilman D, Polasky S, Tiffany D (2006) Environmental, economic, and energetic costs and benefits of biodiesel and ethanol biofuels. Proc Natl Acad Sci USA 103(30):1120611210

Hsieh CH, Wu WT (2009) Cultivation of microalgae for oil production with a cultivation strategy of urea limitation. Bioresour Technol 100(17):3921-3926

Hsu WH, Lee YY, Peng WH, Wu KCW (2011) Cellulosic conversion in ionic liquids (ILs): effects of $\mathrm{H} 2 \mathrm{O} /$ cellulose molar ratios, temperatures, times, and different ILs on the production of monosaccharides and 5-hydroxymethylfurfural (HMF). Catal Today 174(1):65-69

Huang YT, Lee HT, Lai CW (2013) Engineering of the growth environment of microalgae with high biomass and lipid productivity. J Nanosci Nanotechnol 13(3):2117-2121

Illman AM, Scragg AH, Shales SW (2000) Increase in Chlorella strains calorific values when grown in low nitrogen medium. Enzyme Microb Technol 27(8):631-635

Kaur S, Sarkar M, Srivastava RB, Gogoi HK, Kalita MC (2012) Fatty acid profiling and molecular characterization of some freshwater microalgae from India with potential for biodiesel production. N Biotechnol 29(3):332-344

Keffer JE, Kleinheinz GT (2002) Use of Chlorella vulgaris for $\mathrm{CO}_{2}$ mitigation in a photobioreactor. J Ind Microbiol Biotechnol 29(5):275-280

Lee S, Oh Y, Kim D, Kwon D, Lee C, Lee J (2011) Converting carbohydrates extracted from marine algae into ethanol using various ethanolic Escherichia coli strains. Appl Biochem Biotechnol 164(6):878-888

Lv JM, Cheng LH, Xu XH, Zhang L, Chen HL (2010) Enhanced lipid production of Chlorella vulgaris by adjustment of cultivation conditions. Bioresour Technol 101(17):6797-6804

Ma F, Hanna MA (1999) Biodiesel production: a review. Bioresour Technol 70(1):1-15

Maeda K, Owada M, Kimura N, Omata K, Karube I (1995) $\mathrm{CO}_{2}$ fixation from the flue gas on coal-fired thermal power plant by microalgae. Energy Convers Manag 36(6-9):717-720

Marchetti JM, Miguel VU, Errazu AF (2007) Possible methods for biodiesel production. Renew Sustain Energy Rev 11(6): $1300-1311$

Mata TM, Martins AA, Caetano NS (2010) Microalgae for biodiesel production and other applications: a review. Renew Sustain Energy Rev 14(1):217-232

Raja R, Hemaiswarya S, Kumar NA, Sridhar S, Rengasamy R (2008) A perspective on the biotechnological potential of microalgae. Crit Rev Microbiol 34(2):77-88

Ramos AL, Torello CO, Queiroz ML (2010) Chlorella vulgaris modulates immunomyelopoietic activity and enhances the resistance of tumor-bearing mice. Nutr Cancer 62(8):1170-1180

Refaat AA (2009) Correlation between the chemical structure of biodiesel and its physical properties. Int J Environ Sci Technol 6(4):677-694

Refaat AA, Attia NK, Sibak HA, El Sheltawy ST, ElDiwani GI (2008) Production optimization and quality assessment of biodiesel from waste vegetable oil. Int J Environ Sci Technol $5(1): 75-82$

Rippka R, Deruelles J, Waterbury JB, Herdman M, Stanier RY (1979) Generic assignments, strain histories and properties of pure cultures of cyanobacteria. J Gen Microbiol 111(1):1-61

Rosenberg JN, Oyler GA, Wilkinson L, Betenbaugh MJ (2008) A green light for engineered algae: redirecting metabolism to fuel a biotechnology revolution. Curr Opin Biotechnol 19(5):430-436

Sun Z, Liu J, Zeng X, Huangfu J, Jiang Y, Wang M, Chen F (2011) Protective actions of microalgae against endogenous and exogenous advanced glycation endproducts (AGEs) in human retinal pigment epithelial cells. Food Funct 2(5):251-258

Wang L, Wang Y, Chen P, Ruan R (2010) Semi-continuous cultivation of Chlorella vulgaris for treating undigested and digested dairy manures. Appl Biochem Biotechnol 162(8): 2324-2332

Widjaja A, Chien CC, Ju YH (2009) Study of increasing lipid production from fresh water microalgae Chlorella vulgaris. J Taiwan Inst Chem Eng 40(1):13-20

Yeh KL, Chang JS (2012) Effects of cultivation conditions and media composition on cell growth and lipid productivity of indigenous microalga Chlorella vulgaris ESP-31. Bioresour Technol 105: $120-127$

Yeh KL, Chang JS, Chen WM (2010) Effect of light supply and carbon source on cell growth and cellular composition of a newly isolated microalga Chlorella vulgaris ESP-31. Eng Life Sci 10(3):201-208 